\title{
Drivers of brand loyalty in the chain coffee shop industry
}

\begin{abstract}
The present study aimed to examine patrons' loyalty generation process for a chain coffee shop brand by considering the role of cognitive drivers, affective drivers, brand satisfaction, and relationship commitment. A field survey was conducted in chain coffee shops located in the popular shopping districts of a metropolitan city in South Korea. The proposed model was evaluated by using a structural equation analysis. The results revealed that cognitive and affective factors were in general significantly interrelated; such associations along with brand satisfaction and relationship commitment significantly influenced brand loyalty; and, the brand satisfaction was the most important contributor to building brand loyalty. In addition, the mediating role of study variables was identified. Overall, the proposed theoretical framework contained a sufficient level of explanatory power for brand loyalty. With a lack of research about coffee shop customers' purchasing behavior, the findings can be meaningfully used for the enhancement of customer loyalty.
\end{abstract}

Keyword: Relationship commitment; Brand satisfaction; Chain coffee shop; Brand loyalty; Cognition; Affect 